\title{
Determinação de ácido rosmarínico em Cordia verbenacea por cromatografia líquida: aplicabilidade em estudo sazonal
}

\begin{abstract}
MATOS, D.O.1; TIRONI, F.L.2; MARTINS, D.H.N.'; FAGG, C.W. $;$; NETTO JÚNIOR, N.L.2; SIMEONI, L.A.'; MAGALHÃES, P.O.'; SILVEIRA, D. ${ }^{1}$; FONSECA-BAZZO, Y.M. ${ }^{* *}$

'Laboratório de Controle da Qualidade, Faculdade de Ciências da Saúde, Universidade de Brasília, Campus Darcy Ribeiro, Asa Norte, Brasília-DF, Brazil. CEP 70910-900. ${ }^{2}$ Núcleo de Farmácia Viva SES-DF, Avenida Sucupira S/N ${ }^{\circ}$, Riacho Fundo- I, Brasília-DF, Brazil. CEP: 71825-300. ${ }^{3}$ Faculdade de Ceilândia, Universidade de Brasília, Centro Metropolitano, conjunto A, lote 01, Brasília - DF, Brazil. CEP: 72220-900. *Autor para correspondência: yrisfonseca@hotmail.com
\end{abstract}

RESUMO: Neste estudo, uma técnica de cromatografia líquida de alta resolução em fase reversa (CLAE-FR) para a determinação de ácido rosmarínico em Cordia verbenacea foi desenvolvida e validada. A análise de regressão foi avaliada, com observação de uma boa linearidade ( $r$ $=0,9997)$. Os valores obtidos para a precisão e exatidão estão de acordo com as diretrizes do ICH e com a legislação brasileira. Os valores de repetibilidade e precisão intermediária foram $2,79 \%$ e $4,76 \%$, respectivamente. Os limites de detecção e de quantificação de ácido rosmarínico foram de $1,92 \mu \mathrm{g} / \mathrm{mL}$ e $5,81 \mu \mathrm{g} / \mathrm{mL}$, respectivamente. Os resultados mostraram que o método desenvolvido é uma técnica por CLAE-FR de confiança para a determinação de ácido rosmarínico em tintura de $C$. verbenacea. Além disso, essa metodologia foi aplicada em estudo sazonal, que revela uma correlação positiva relativamente forte entre o período de chuvas e o teor de ácido rosmarínico.

Palavras-chave: Cordia verbenacea, ácido rosmarínico, CLAE.

\begin{abstract}
Determination of rosmarinic acid in Cordia verbenacea by liquid chromatography: applicability in seasonal study. In this study, a reverse phase-high performance liquid chromatography (RP-HPLC) technique for determination of rosmarinic acid in the Cordia verbenacea was developed and validated. A regression analysis was performed, with the observation of good linearity $(r=0.999949)$. The values obtained for precision and accuracy determination are in agreement with $\mathrm{ICH}$ guidelines and the Brazilian legislation. The values of repeatability and intermediate precision were $2.79 \%$ and $4.76 \%$, respectively. The detection and the quantitation limits of the rosmarinic acid were $1.92 \mu \mathrm{g} / \mathrm{mL}$ and $5.81 \mu \mathrm{g} /$ $\mathrm{mL}$, respectively. The results demonstrated that the developed method is a reliable RP-HPLC technique for the determination of rosmarinic acid in C. verbenacea tincture. In addition, this methodology was applied at a seasonal study indicating relatively strong positive correlation between the rain period and the rosmarinic acid content.
\end{abstract}

Keywords: Cordia verbenacea, rosmarinic acid, HPLC.

\section{INTRODUCTION}

Cordia verbenacea DC (synonyms: Varronia verbenacea (DC.) Borhidi, Varronia curassavica Jacq) is a native Brazilian medicinal plant belonging to the family Boraginaceae, widely distributed along the southeast coast of Brazil (Passos et al., 2007). This bushy plant is popularly known as "cordia, blacksage, wild-sage, orégano-cimarrón, erva baleeira" (Roldão et al., 2008).

In folk medicine, in the Brazilian Amazon, native tribes use Cordia leaves in infusion to treat infections of all kinds, rheumatism and arthritis (Akisue et al., 1983). Pharmacological studies have shown that the $C$. verbenaceae has been used in the form of alcoholic extracts, decoctions and infusions (Fernandes et al., 2007). The described properties are anti-ulcer (Falcão et al., 2008; Roldão et al., 2008), anti-microbial (Michielin et al., 2009), antiinflammatory (Ticli et al., 2005; Fernandes et al., 
2007; Passos et al., 2007) and analgesic (Roldão et al., 2008).

Several compounds are found in the aerial parts of $C$. verbenacea including $\alpha$-pinene, trans-cariophyllene, aloaromadendrene, cordialin A, cordialin B, rosmarinic acid and flavanols (Thirupathi et al., 2008). The main compounds found in essential oil are trans-caryophyllene, a-humulene (Passos et al., 2007; Fernandes et al., 2007), and others compounds as spathulenol, $\beta$-sitosterol and eugenol (Michielin et al., 2009). In addition, lupeol, bisabolol, farnesyl acetate and artemetin have been found in $C$. verbenacea extracts obtained by different extraction process (Michielin et al., 2009). Santi et al. (2014) reports presence of flavonoid derivatives in C. verbenacea leaves by HPLC.

Rosmarinic acid is a phenolic compound widely distributed in various plants such as Ocimum basilicum, Melissa officinalis, Rosmarinus officinalis, Mentha spicata, e Perilla frutescen e C. verbenacea (Makino et al., 2002; Ticli et al., 2005), commonly found in species from Boraginaceae family. In addition, this compound is the phytochemical marker to $C$. verbenaceae due its properties and abundance in this species.

About pharmacological activity, rosmarinic acid is reported exhibiting anti-inflammatory effects, including inhibition of $\mathrm{C}_{3}$ convertase, $\mathrm{C}_{5}$-convertase, 5-lipoxygenase, histamine release from mast cells, phospholipase $\mathrm{A}_{2}$ and sequesters reactive oxygen species (Makino et al., 2002; Ticli et al., 2005; dos Santos et al., 2010).

In this study, a reverse phase-high performance liquid chromatography (RP-HPLC) technique for determination of rosmarinic acid in $C$. verbenacea tincture was developed and validated. In addition, the applicability of this method in seasonal study was investigated.

\section{MATERIALS AND METHODS \\ Plants and Chemicals}

Cordia verbenacea leaves were collected in Garden of Center for Living Pharmacy (Farmácia Viva) of the Federal District - Brazil. The species was identified by comparison with a voucher specimen deposited at the Herbarium of the Universidade de Brasília by number FaggCW 2237.

Phosphoric acid (HPLC grade) and rosmarinic acid were supplied by Sigma-Aldrich (St Louis, MO, USA). Acetonitrile (ACN) and methyl alcohol $(\mathrm{MeOH})$ for use in chromatography and spectrophotometry were purchased from Tedia (USA). The water used to prepare the solutions or mobile phase was purified in a Milli-Q-plus System (Millipore, Bedforte, MA, USA).
Preparation of Cordia verbenacea tincture

C. verbenacea leaves were dried at room temperature $\left(25^{\circ} \mathrm{C}\right)$. Dried leaves showed $5-10 \%$ moisture. The tincture was obtained by maceration ( 2 hours) following by percolation process ( 3-5 $\mathrm{mL} / \mathrm{min}$.) using ethyl alcohol $70^{\circ} \mathrm{GL}$ in the ratio $1: 2$ (leaves:solvent). Three different extractions were prepared and analyzed by HPLC. All extracts were stored at $-20^{\circ} \mathrm{C}$ until the time of analysis.

\section{DETERMINATION OF ROSMARINIC ACID BY HPLC \\ Apparatus and chromatographic conditions \\ C. verbenacea tincture was analyzed using} LaChrom Elite HPLC system (Hitachi, Tokyo, Japan) liquid chromatograph equipped with L2130 pump, L2200 auto-sampler; L2300 column oven was set at $25^{\circ} \mathrm{C}$ and a L2455 DAD detector (Hitachi, Tokyo, Japan). The detector was set at $330 \mathrm{~nm}$. Separation was performed by Purospher Star reverse phase C18e column ( $5 \mu \mathrm{m}, 150 \mathrm{~mm}$ x 4.6 $\mathrm{mm}$ i.d.) in combination with an appropriate guard column ( $4 \times 4 ; 5 \mu \mathrm{m}$ particle size) (Merck, Germany). The eluents used were: aqueous phosphoric acid (1\%) (solvent A) and acetonitrile (solvent B). The gradient employed was: $80 \%$ A and $20 \%$ B for 0 min, $60 \% \mathrm{~A}$ and $40 \% \mathrm{~B}$ for $30 \mathrm{~min}, 30 \% \mathrm{~A}$ and $70 \%$ $B$ for $35 \mathrm{~min}, 5 \% \mathrm{~A}$ and $95 \% \mathrm{~B}$ for $50 \mathrm{~min}$, at a flow rate of $0.8 \mathrm{~mL} / \mathrm{min}$. Data acquisition was performed using EZChrom Elite software (version 3.3.2 SP1 (Scientific Software. Inc.).

Sample solution was prepared diluting $50 \mu \mathrm{L}$ of tincture into $1.0 \mathrm{~mL} \mathrm{MeOH}$. The obtained solution was then filtered. The compounds in the tincture were characterized according to their UV-Vis spectra and identified by their retention times in comparison with those of commercial standards.

\section{Validation}

Validation was performed following the $\mathrm{ICH}$ guidelines ( $\mathrm{ICH}, 1996)$ ) and Brazilian legislation (Brasil, 2003; Brasil, 2012). The method was validated considering the parameters selectivity, linearity, accuracy, precision, limit of detection, limit of quantitation and robustness.

Selectivity of this method proposed was evaluated. The appropriate method for quantification should demonstrate selectivity for detecting the analyte in the presence of degradation products. As far we know, there is no report about degradation products of $C$.verbenacea, so the comparison between results from degraded samples and the results from non-degraded samples was established. For that, $1.0 \mathrm{~mL}$ of the tincture was accurately weighed, and then $2 \mathrm{~mL}$ of $\mathrm{HCl} 1 \mathrm{M}$ or $\mathrm{NaOH} 1 \mathrm{M}$ was added and placed in a water bath maintained at $60^{\circ} \mathrm{C}$ for $1 \mathrm{~h}$. The mixture was cooled, and the $\mathrm{pH}$

Rev. Bras. PI. Med., Campinas, v.17, n.4, supl. II, p.857-864, 2015. 
solution was adjusted to about 7.0 with $2 \mathrm{~mL} \mathrm{HCl} 1 \mathrm{M}$ or $\mathrm{NaOH} 1 \mathrm{M}$ (Sistla et al., 2005; Leite et al., 2014). After that, $35.0 \mathrm{~mL}$ of methanol was added to the mixture. Then, the obtained products were analyzed for the presence of both intact and degraded drug by the proposed procedure comparing with a control sample.

Linearity was checked with standard solutions of rosmarinic acid in the concentration range of $2.5-1000.0 \mu \mathrm{g} / \mathrm{mL}$. The standard curves were analyzed by linear regression of peak area versus rosmarinic acid concentration.

Precision was expressed as relative standard deviation (RSD \%) and was determined by repeatability (intra-day) and intermediate precision (inter-day). Repeatability was evaluated by analysis of six replicates of the same extract in the same day under the same experimental conditions. The intermediate precision was studied on three different days.

The accuracy experiments applied the standard addition method (rosmarinic acid) in the sample (C. verbenacea tincture), using replicates (n $=3$ ) of three different rosmarinic acid concentrations.

For that, the $C$. verbenacea tincture solution was prepared adding $500 \mu \mathrm{L}$ of tincture $(43.6 \mu \mathrm{g} /$ $\mathrm{mL}$ of rosmarinic acid) to $500 \mu \mathrm{L}$ of rosmarinic acid solution in the concentration of $24.4 \mu \mathrm{g} / \mathrm{mL}, 36.4 \mu \mathrm{g} /$ $\mathrm{mL}$ and $48.4 \mu \mathrm{g} / \mathrm{mL}$, in order to obtain rosmarinic acid theoretical final concentrations of 34.0 (A), 40.0 (B) and $46.0 \mu \mathrm{g} / \mathrm{mL}$ (C).

Finally, the solutions were filtered and analyzed by the developed HPLC method. Accuracy was expressed as percent of recovery, which was estimated as the relation between the experimental concentrations and the theoretical concentrations $\left[\left(C_{e} / C_{t}\right) \times 100\right]$.

The limit of detection (LOD) and limit of quantitation (LOQ) were determined on the basis of the standard deviation of the response and the slope of the constructed calibration curve. The LOD was expressed as $\left(3.3 \times \sigma^{\prime}\right) / S$ and the LOQ was expressed as $\left(10 \times \sigma^{\circ}\right) / S$, where o is the standard deviation of the response and $S$ is the slope of calibration curve.

Robustness was examined by evaluating the influence of small variation in the experimental parameters on the analytical performance of the proposed method. The studied parameters were: variation of wavelength $(320-340 \mathrm{~nm})$, flow (0.6-1.0 $\mathrm{mL} / \mathrm{min}$.) and temperature $\left(23-27^{\circ} \mathrm{C}\right)$. The effects on the parameters retention time and peak area were observed.

\section{METHOD APPLICATION \\ Applicability in seasonal study}

The seasonal variation of rosmarinic acid content in C. verbenacea leaves was evaluated by the validated HPLC method. Cordia verbenacea leaves were cultivated and collected on 13 September 2012 (winter), 19 March 2013 (autumn) and 14 May 2013 (autumn). For that, C. verbenacea tincture was prepared by same technique described before. Rosmarinic acid content was associated with the average rainfall data in Brasilia (Federal District) between 2000 and 2013 (Meteonews, 2013). Data were subjected to Pearson correlation analysis.

\section{RESULTS}

Determination of rosmarinic acid by HPLC

The chromatography profile of $C$. verbenacea tincture presents a large number of compounds (figure 1). Twelve main peaks were observed. It was possible to identify the main peak, rosmarinic acid, by comparison with commercial standards (SigmaAldrich, USA). Chemical structure of rosmarinic acid is shown in Figure 1. In identification of rosmarinic acid was observed that retentions time of the rosmarinic acid standard and co-injections with sample were the same. In addition, peak purity in both, rosmarinic standard and co-injections, were 0.9999 . The rosmarinic content found in $C$. verbenacea tincture was about $794.88 \pm 22.68 \mu \mathrm{g} /$ $\mathrm{mL}$.

\section{Validation}

The chromatographic analysis developed for quantitative determination of this polyphenol was validated according to $\mathrm{ICH}$ guidelines (ICH, 1996) and Brazilian legislation (Brazil, 2012; Brazil, 2003).

Selectivity was demonstrated by average of the changes in retention time and peak area of rosmarinic acid in degraded samples (Table 1 and 2). Firstly, it was observed that there was degradation of the sample in the induced acid and basic hydrolysis. It was observed reduction of rosmarinic acid content and the formation of degradation products, since the sample control showed twelve main peaks, while samples of the basic hydrolysis showed additional peaks in 7.26, 8.64, 9.02, 9.58, 37.20, 42.86, 43.85 e 54.32 minutes. Furthermore, we did not observe the peaks at $12.71,15.07,16.66,18.39,30.19,46.7$ and 50.6 minutes. In the acid hydrolysis product chromatogram, an additional peak at 27.66 minutes was observed (Table 1 and 2).

The retention time of degradation products did not show similarity to retention time of rosmarinic acid. In addition, all peaks of rosmarinic acid had good purity index in different analyzed groups.

In relation to the peak area, the rosmarinic

Rev. Bras. PI. Med., Campinas, v.17, n.4, supl. II, p.857-864, 2015. 


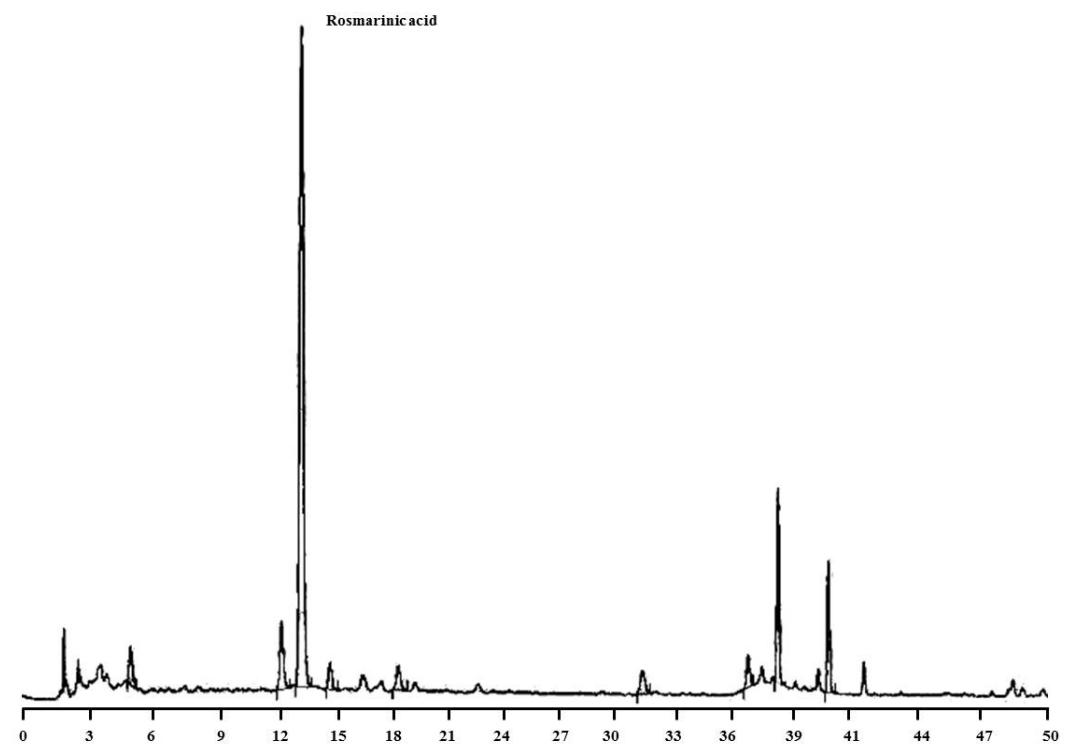

FIGURE 1. Typical chromatogram of Cordia verbenacea tincture.

TABLE 1.Retention time and wavelength of maximum absorption of the compounds present Cordia verbenacea tincture after that induced degradation by basic and acid hydrolysis

\begin{tabular}{lllllll}
\hline & Control & \multicolumn{5}{l}{ Acid hydrolysis } \\
\hline Peak & Retention Time & $\lambda$ max. & Retention Time & $\lambda$ max. & Retention Time & $\lambda$ max. \\
\hline 1 & - & - & $7.26 \pm 0.01^{\mathrm{b}}$ & 357 & - & - \\
2 & - & - & $8.64 \pm 0.01^{\mathrm{b}}$ & 391 & - & - \\
3 & - & - & $9.02 \pm 0.01^{\mathrm{b}}$ & 397 & - & - \\
4 & - & - & $9.58 \pm 0.01^{\mathrm{b}}$ & 396 & - & - \\
5 & $12.71 \pm 0.06$ & 389 & - & - & $12.69 \pm 0.02$ & 327 \\
$6^{\mathrm{a}}$ & $13.67 \pm 0.05$ & 329 & $13.62 \pm 0$ & 394 & $13.66 \pm 0.01$ & 329 \\
7 & $15.07 \pm 0.06$ & 312 & - & - & $15.09 \pm 0.01$ & 315 \\
8 & $16.66 \pm 0.05$ & 389 & - & - & $16.69 \pm 0.01$ & 309 \\
9 & $18.39 \pm 0.07$ & 389 & - & - & $18.37 \pm 0.01$ & 397 \\
10 & - & - & - & - & $27.66 \pm 0.01^{\mathrm{b}}$ & 387 \\
11 & $30.24 \pm 0.03$ & 351 & - & - & $30.28 \pm 0.01$ & 351 \\
12 & $35,36 \pm 0.02$ & 343 & $35.37 \pm 0$ & 346 & $35.39 \pm 0.01$ & 345 \\
13 & $36.81 \pm 0.01$ & 357 & $36.82 \pm 0.01$ & 348 & $36.82 \pm 001$ & 348 \\
14 & - & - & $37.20 \pm 0.01^{\mathrm{b}}$ & 284 & - & - \\
15 & $39.26 \pm 0.01$ & 347 & $39.29 \pm 0.01$ & 347 & $39.28 \pm 0.01$ & 347 \\
16 & $40.98 \pm 0.02$ & 396 & $41.02 \pm 0.01$ & 338 & $41.02 \pm 0.01$ & 398 \\
17 & - & - & $42.86 \pm 0.01^{\mathrm{b}}$ & 323 & - & - \\
18 & - & - & $43.85 \pm 0.01^{\mathrm{b}}$ & 301 & - & - \\
19 & 46.7 & 324 & - & - & - & - \\
20 & 50.59 & 324 & - & - & $50.59 \pm 0$ & 324 \\
21 & - & - & $54.32 \pm 0.01^{\mathrm{b}}$ & 359 & - & - \\
\hline
\end{tabular}

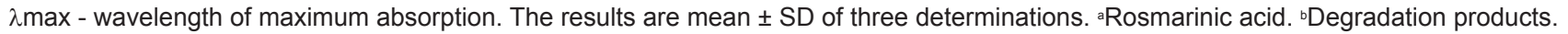

acid content was reduced in $55.46 \%$ in the basic hydrolysis, according to Student's t-test, but the acid hydrolysis did not promote reduction of rosmarinic acid content.

Under the experimental conditions, the linearity was maintained within the considered concentration range. A regression analysis was performed, with the observation of the good linearity $(r=0.999949)$ and the representative linear equation was $y=286800 x+239300$ for rosmarinic acid. Table 3 summarizes the results of the regression analysis and shows the slope, intercept and correlation coefficient. The detection and quantitation limits of rosmarinic acid were $1.92 \mu \mathrm{g} / \mathrm{mL}$ and $5.81 \mu \mathrm{g} / \mathrm{mL}$, respectively (Table 3 ). 
TABLE 2. Peak area of the compounds present Cordia verbenacea tincture after that induced degradation by basic and acid hydrolysis

\begin{tabular}{llll}
\hline Peak area & & & \\
\hline Peak & Control & Basic hydrolysis & Acid hydrolysis \\
\hline 1 & - & $273594.7 \pm 1461.57^{\mathrm{b}}$ & - \\
2 & - & $1708844 \pm 20025.85^{\mathrm{b}}$ & - \\
3 & - & $300299.3 \pm 8403.44^{\mathrm{b}}$ & - \\
4 & - & $588014 \pm 8193.54^{\mathrm{b}}$ & $424473 \pm 4785.33$ \\
5 & $978247 \pm 239982.5$ & - & $10233594 \pm 319563.6$ \\
$6^{\mathrm{a}}$ & $10305765 \pm 1489198$ & $459044.7 \pm 1914.33^{\mathrm{*}}$ & $338518,7 \pm 6913.84$ \\
7 & $393638.3 \pm 60871.72$ & - & $237793 \pm 7725$ \\
8 & $319143 \pm 75836.74$ & - & $480411 \pm 7874.74$ \\
9 & $443399 \pm 109574.4$ & - & $517500.7 \pm 20774.23^{\mathrm{b}}$ \\
10 & - & - & $404552.3 \pm 9743.95$ \\
11 & $440748.3 \pm 102755.5$ & - & $390563.7 \pm 4945.73$ \\
12 & $399871.3 \pm 100213.5$ & $386293.3 \pm 3627.70$ & $1665091 \pm 25095.87$ \\
13 & $1777675 \pm 422452.7$ & $1653987 \pm 22188.42$ & - \\
14 & - & $406306.3 \pm 16353.78^{\mathrm{b}}$ & $1129458 \pm 22162.86$ \\
15 & $1204795 \pm 285148.4$ & $1105073 \pm 15093.91$ & $292427.3 \pm 8292.68$ \\
16 & $321277,7 \pm 73754.33$ & $290558 \pm 3801.37$ & - \\
17 & - & $230988 \pm 1149^{*}$ & - \\
18 & - & $390175 \pm 10847.75^{\mathrm{b}}$ & - \\
19 & 1039089 & - & $2226332 \pm 0^{\mathrm{b}}$ \\
20 & 272801 & - & - \\
21 & - & $292222 \pm 20410.8^{\mathrm{b}}$ & \\
\hline
\end{tabular}

The results are mean \pm SD of three determinations.

The results are mean $\pm S D$ of three experiments. $r$ - Correlation coefficient. LOD: detection limit and LOQ: quantitation limit.

Repeatability and intermediate precision were $2.79 \%$ and $4.76 \%$, respectively. The mean of peak area, rosmarinic acid content and the relative standard deviation are reported in Table 4.

The accuracy of the method was determined by adding known amount of rosmarinic acid standard in C. verbenacea tincture samples at three known levels of concentration. The mean values of the percentage analytical recoveries for the concentration of $34.0,40.0$ and $46.0 \mu \mathrm{g} / \mathrm{mL}$ of rosmarinic acid were $96.29 \%, 94.72 \%$ and $96.53 \%$, respectively (Table 4 ).

The results are mean $\pm S D$ of three experiments. a Six replicates were assayed on the same day. ${ }^{\circ}$ Six replicates were assayed on three different days. A-Low concentration, B-intermediate concentration and $\mathrm{C}-$ high concentration.

In the Robustness assay, no change in retention time or peak area was observed when variations of wavelength were established. However, flow variations were able to cause changes in retention time and peak area at $1.0 \mathrm{~mL} / \mathrm{min}$. Change in peak area and retention time were found when variations of temperature were established (Figure 2).

The results are mean \pm SD of three determinations. A: peak area variation and $B$ : retention time variation. Statistical analysis was performed using Student's $t$-test. ${ }^{*} \mathrm{p}<0.05$ peak area or retention time significantly reduced compared by the best conditions for separating compounds present in $C$. verbenaceae tincture: wavelength of $330 \mathrm{~nm}$, flow rate of $0.8 \mathrm{~mL} / \mathrm{min}$ and temperature of $25^{\circ} \mathrm{C}$.

\section{Applicability in seasonal study}

The seasonal variation of rosmarinic acid content in $C$. verbenacea leaves was associated with the average rainfall data in Brasilia (Federal District) between 2000 and 2013 (Meteonews, 2013). It was observed correlation between the period of rains and the content of rosmarinic acid. In March, rosmarinic acid content was $3931.68 \mu \mathrm{g} / \mathrm{mL}$, in this month the precipitation amount was $20.0 \mathrm{~mm}$, rainy season. In May, the precipitation amount was reduced to 2.0 $\mathrm{mm}$ and rosmarinic acid content reduced $12.05 \%$ $(3457.84 \mu \mathrm{g} / \mathrm{mL})$ in relation to March, beginning of the dry season. In September, rosmarinic content reduced $79.73 \%(797.71 \mu \mathrm{g} / \mathrm{mL})$, in this month the precipitation amount was $4.0 \mathrm{~mm}$, ending of the dry season (Figure 3 ). The correlation between rainfall and rosmarinic acid content was 0.62 , positive correlation relatively strong by the classification of Callegari-Jacques (2003).

\section{DISCUSSION}

Plant extracts are composed of many substances and are capable of variation depending 
TABLE 3. HPLC method validation parameters: linearity, detection limit and quantitation limit

\begin{tabular}{|c|c|c|c|c|c|c|}
\hline \multicolumn{7}{|c|}{ Linearity } \\
\hline & Concentration range $(\mu \mathrm{g}$ & $\mathrm{mL})$ & Slope & & tercept & $r$ \\
\hline Rosmarinic acid & $50-250$ & & $286800 \pm 1350$ & 239 & $0 \pm 187400$ & 0.999949 \\
\hline \multicolumn{7}{|c|}{ Detection limit (LOD) and quantitation limit (LOQ) } \\
\hline & $\begin{array}{c}\text { Concentration range }(\mu \mathrm{g} / \\
\mathrm{mL})\end{array}$ & Slope & $\begin{array}{r}\text { Standard dev } \\
\text { interc }\end{array}$ & of $y-$ & $\begin{array}{l}\mathrm{LOD}(\mu \mathrm{g} / \\
\mathrm{mL})\end{array}$ & $\begin{array}{c}\mathrm{LOQ} \\
(\mu \mathrm{g} / \mathrm{mL})\end{array}$ \\
\hline Rosmarinic acid & $1.0-25.0$ & 258700 & 1502 & & 1.92 & 5.81 \\
\hline
\end{tabular}

TABLE 4. HPLC method validation parameters: precision and accuracy

\begin{tabular}{|c|c|c|c|c|c|c|}
\hline \multicolumn{7}{|c|}{ Precision } \\
\hline & & \multicolumn{2}{|c|}{ Peak area } & RSD (\%) & Rosmarinic acid $(\mu \mathrm{g} / \mathrm{mL})$ & RSD (\%) \\
\hline & atability a & \multicolumn{2}{|c|}{$11640000 \pm 325200$} & 2.79 & $794.88 \pm 22.68$ & 2.85 \\
\hline & nediate precision ${ }^{\mathrm{b}}$ & \multicolumn{2}{|c|}{$12440419 \pm 592497$} & 4.76 & $799.49 \pm 52.89$ & 6.62 \\
\hline \multicolumn{7}{|c|}{ Accuracy of the HPLC method } \\
\hline & \multicolumn{2}{|c|}{ Rosmarinic acid added $(\mu \mathrm{g} / \mathrm{mL})$} & \multicolumn{2}{|c|}{ Rosmarinic acid found $(\mu \mathrm{g} / \mathrm{mL})$} & \multicolumn{2}{|l|}{ Recovery (\%) } \\
\hline A & \multicolumn{2}{|l|}{34.0} & \multicolumn{2}{|l|}{$32.74 \pm 1.71$} & \multicolumn{2}{|l|}{$96.29 \pm 5.04$} \\
\hline$B$ & \multicolumn{2}{|l|}{40.0} & \multicolumn{2}{|l|}{$37.89 \pm 0.19$} & \multicolumn{2}{|l|}{$94.72 \pm 0.47$} \\
\hline $\mathrm{C}$ & \multicolumn{2}{|l|}{46.0} & \multicolumn{2}{|l|}{$44.40 \pm 0.37$} & $96.53 \pm 0.80$ & \\
\hline
\end{tabular}

${ }^{a}$ Rosmarinic acid. ${ }^{b}$ Degradation products. Statistical analysis was performed using Student's $t$-test. " $p<0.05$ peak area significantly reduced compared by control without hydrolysis.

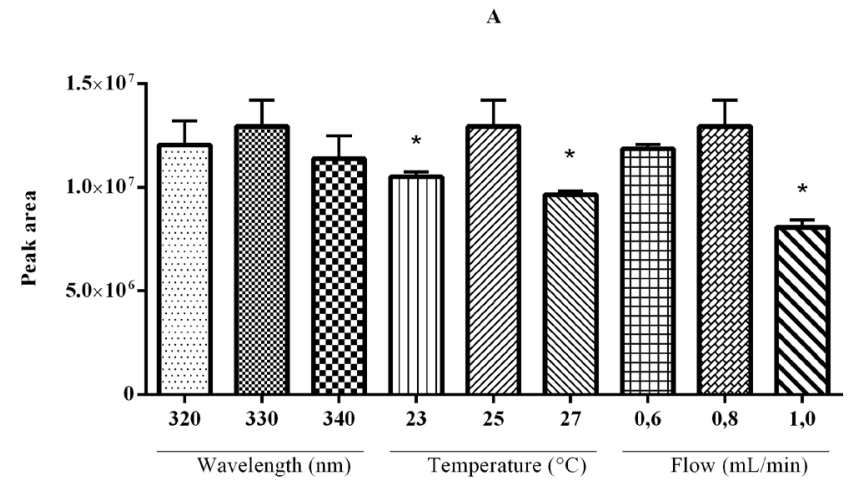

FIGURE 2. Robustness assay.

on various factors. So, to ensure their efficacy and safety, it is needed to standardize these extracts and assure their pharmaceutical quality.

In the present work, RP-HPLC with UV detection and linear gradient mobile phase mode was proposed as a suitable method for quantitative determination of rosmarinic acid in C. verbenacea tincture. In addition, the applicability of this method and seasonal study was investigated.

Cordia verbenacea is an important species since its derivatives have been used in herbal medicines. However, unlike other herbal drugs, there is a lack of reports about rosmarinic acid amount range in this species, as well as, about validated methodology using DAD-HPLC for quantification of rosmarinic acid.

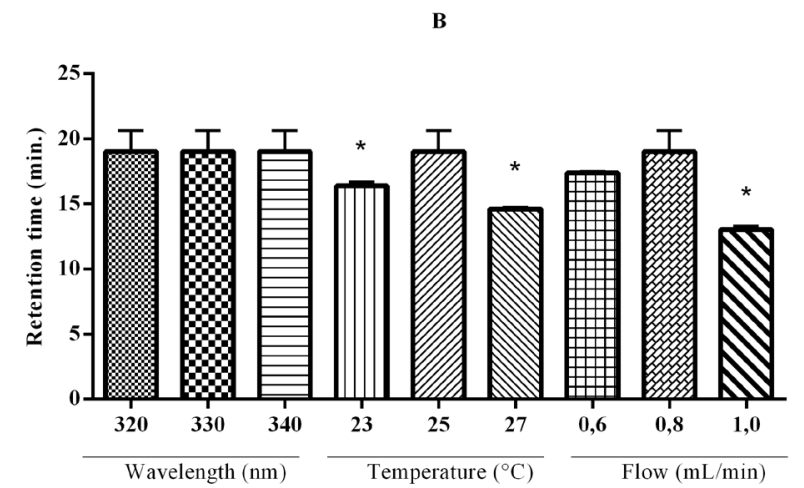

Rosmarinic acid has been described in several plants, commonly found in species of Boraginaceae and the subfamily Nepetoideae of the Lamiaceae (Petersen \& Simmon, 2003).

The developed chromatographic analysis for quantitative determination of this polyphenol was validated to obtain reproducible analysis with a high degree of accuracy and precision in the range of concentrations investigated.

The tincture was subjected to stress testing by acid and basic hydrolysis, to check whether the method is able to separate impurities and degradation products of the reference compound rosmarinic acid. The results showed that the proposed method demonstrates selectivity for detecting rosmarinic acid in the presence of their degradation products. 


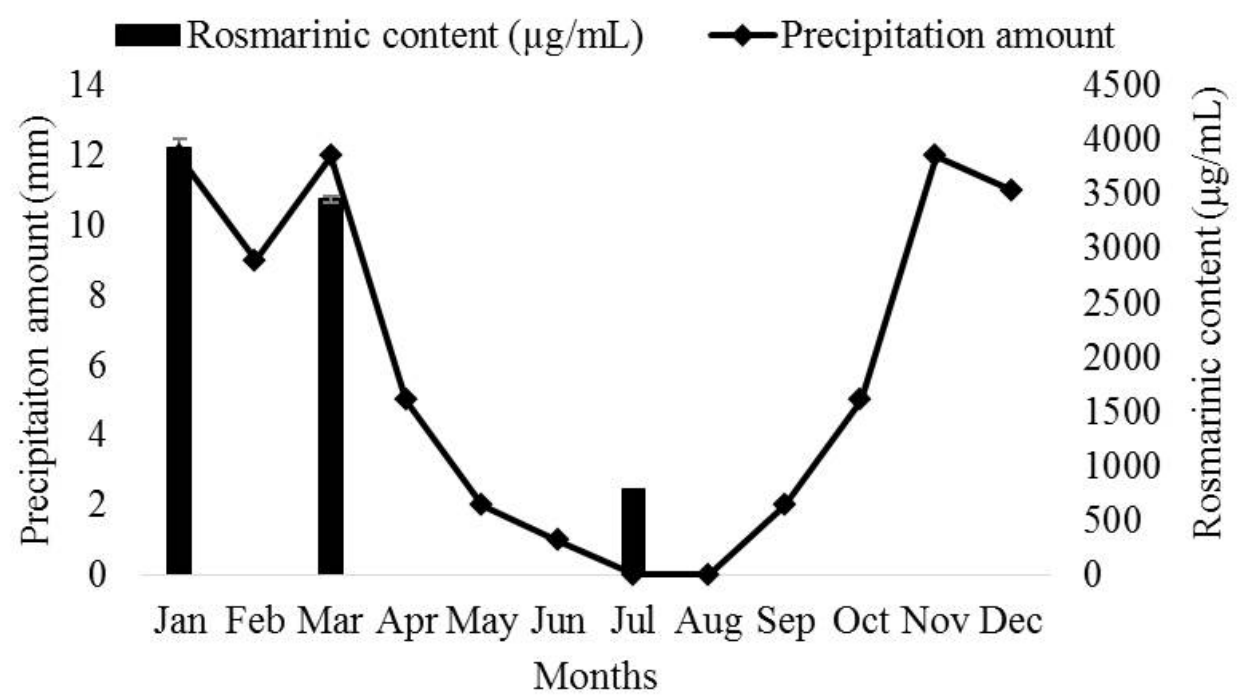

FIGURE 3. Seasonal variation of rosmarinic acid content $(\mu \mathrm{g} / \mathrm{mL})$ in leaves of Cordia verbenacea in relation to average precipitation amount $(\mathrm{mm})$ in Brasilia (Federal District) between 2000 and 2013.

A regression analysis was performed, with the observation of good linearity in a wide concentration range. The obtained values for precision and accuracy determination are in agreement with $\mathrm{ICH}$ and ANVISA requeriments $(\mathrm{ICH}$, 1996; Brasil, 2003; Brasil, 2012), which indicated that the chromatographic conditions used are reliable to quantify the rosmarinic acid in the evaluated range. Lopes et al. (2012) described similar results by using a methodology for the determination of derivatives of o-hydroxycinnamic acid from Echinodorus grandiflorus.

In addition, the detection and the quantitation limits of rosmarinic acid were established. Despite small changes in the peak area and retention time, the flow rate and the temperature are analytical parameters that should be controlled to get better analytical performance of the proposed method. The analytical parameter: wavelength of $330 \mathrm{~nm}$, flow rate of $0.8 \mathrm{~mL} / \mathrm{min}$. and temperature of $25^{\circ} \mathrm{C}$ proved to be the best conditions for separating compounds from $C$. verbenaceae tincture.

Considering the importance of this species and its derivatives, and because there are herbal medicines from this plant in the Brazilian market, this study may contribute to the development of $C$. verbenacea monograph to be insert in future editions of the Brazilian Pharmacopoeia.

It is the first time a study of seasonal variation of the rosmarinic acid content in $\mathrm{C}$. verbenacea was done. It was observed that the rosmarinic acid content in Cordia verbenacea leaves varies with seasons. At District Federal, there are 2 characteristic seasons - dry and rain periods. It was observed positive correlation relatively strong between the period of rain and rosmarinic acid content. These results reveal that the higher the amount of rainfall increases rosmarinic acid content synthesized by this plant. The best seasonal period to collect this medicinal plant should be the rainy season, March month, due high rosmarinic acid content found. These results corroborate with Palá-Paúl et al. (2001), essential oil concentration in Santolina rosmarinifolia L. ssp. rosmarinifolia showed significant correlations with both precipitation (positive) and temperature (negative). In addition, Gobbo-Neto \& Lopes (2007) reported that the water stress often alter the concentrations of secondary metabolites in plants.

\section{CONCLUSION}

The developed method shows to be a reliable HPLC technique for determination of rosmarinic acid in Cordia verbenacea tincture. This described method may be applied to the standardization of herbs, extracts or commercialized herbal medicines, as well as to perform stability studies of this plant drug. In addition, the best seasonal period to collect this medicinal plant should be the rainy season, because it was observed the highest rosmarinic acid amount in the leaves.

\section{ACKNOWLEDGMENTS}

The authors are grateful to Coordination for the Improvement of Higher Education Personnel (CAPES); National Council for Scientific and Technological Development (CNPq), Decanato de Pesquisa e Pós-Graduação-UnB (DPP/UnB) and Fundação de Apoio à Pesquisa do Distrito Federal (FAPDF) for financial support. 


\section{REFERENCES}

AKISUE, M.K. et al. Caracterização farmacognóstica da droga e da tintura de Cordia verbenacea A. DC.-BORAGINACEAE. Revista de Ciências Farmacêuticas, v.5, p.69-82, 1983.

BRASIL. Agência Nacional de Vigilância Sanitária. Resolução $n^{\circ} 27$, de 17 de maio de 2012. Dispõe sobre os requisitos mínimos para a validação de métodos bioanalíticos empregados em estudos com fins de registro e pós-registro de medicamentos. Diário Oficial da União, Brasília. DOU de 22/05/2012.

BRASIL. Agência Nacional de Vigilância Sanitária. Resolução $n^{\circ} 899$, de 29 de maio de 2003. Guia para validação de métodos analíticos e bioanalíticos. Diário Oficial da União, Brasília. DOU de 02/06/2003.

CALLEGARI-JACQUES, S.M. Bioestatística: Princípios e Aplicações. São Paulo: Editora Artmed S.A.

SANTOS, J.I.; et al., Crystallization and preliminary X-ray crystallographic studies of a Lys49-phospholipase A2 homologue from Bothrops pirajai venom complexed with rosmarinic acid. Acta Crystallographica. Section F, Structural Biology Communications, v.6, p.699701, 2010.

FALCÃO, H.S.; et al., Plants of the American continent with antiulcer activity. Phytomedicine,v.15, p.132-46, 2008.

FERNANDES, E.S.; et al Anti-inflammatory effects of compounds alpha-humulene and (-)-trans-caryophyllene isolated from the essential oil of Cordia verbenacea. European Journal of Pharmacology, v.569, p.22836, 2007.

GOBBO-NETO, L.; LOPES, N.P. Plantas medicinais: fatores de influência no conteúdo de metabólitos secundários. Química Nova, v. 30, n. 2, p. 374, 2007.

$\mathrm{ICH}$. International Conference on Harmonisation Harmonised Tripartite Guideline: Topic Q2B. Note for guidelines on Validation of Analytical Procedure: Methodology. International Conference on Harmonisation, 1996.

LEITE, C.F.M; et al., Determination of rutin in Erythroxylum suberosum extract by liquid chromatography: applicability in standardization of herbs and stability studies. Boletin Latinoamericano y del Caribe de Plantas Medicinales y Aromaticas, v.13, n.2, p.135-143, 2014.
LOPES, G.C.; et al., Validação de metodologia analítica para a determinação de derivados do ácido o-hidroxicinâmico de Echinodorus grandiflorus. Revista brasileira de plantas medicinais, v. 14 , n. 3 , p. 500 505, 2012.

MAKINO, T.; et al., effects of rosmarinic acid on mesangioproliferative glomerulonephritis in rats. Nephron, v.92, p.898-904, 2002.

MICHIELIN, E.M.; et al., Chemical composition and antibacterial activity of Cordia verbenacea extracts obtained by different methods. Bioresource Technology, v.100, p.6615-23, 2009.

PALÁ-PAÚL, J. et al. Seasonal variation in chemical constituents of Santolina rosmarinifolia L. ssp. rosmarinifolia. Biochemical systematics and ecology, v. 29, n. 7, p. 663-672, 2001.

PASSOS, G.F.; et al., Anti-inflammatory and antiallergic properties of the essential oil and active compounds from Cordia verbenacea. Journal of Ethnopharmacology, v.110, p.323-33, 2007.

PETERSEN, M.; Simmonds, M.S.J. Rosmarinic acid. Phytochemistry, v. 62, n. 2, p. 121-125, 2003.

ROLDÃO, E.F.; et al., Evaluation of the antiulcerogenic and analgesic activities of Cordia verbenacea DC. (Boraginaceae). Journal of Ethnopharmacology, v.119, p.94-8, 2008.

SANTI, M.M.; et al., Determinação do perfil fitoquímico de extrato com atividade antioxidante da espécie medicinal Cordia verbenacea DC. por HPLC-DAD. Revista Brasileira de Plantas Medicinais, v.16, n.2, p.256-261, 2014.

SISTLA, R.; et al.,Development and validation of a reversed-phase HPLC method for the determination of ezetimibe in pharmaceutical dosage forms. Journal of Pharmaceutical and Biomedical Analysis, v.39, p.517-22, 2005.

THIRUPATHI, K.; et al., A review of medicinal plants of the genus Cordia: Their chemistry and pharmacological uses. Journal of Natural Remedies, v.8, p.1-10, 2008.

TICLI, F.K.; et al., Rosmarinic acid, a new snake venom phospholipase A2 inhibitor from Cordia verbenacea (Boraginaceae): antiserum action potentiation and molecular interaction. Toxicon, v.46, p.318-27, 2005.

Rev. Bras. PI. Med., Campinas, v.17, n.4, supl. II, p.857-864, 2015. 